\title{
Roles of Bacterial Symbionts in Transmission of Plant Virus by Hemipteran Vectors
}

\author{
Wei Wu, Hong-Wei Shan, Jun-Min Li, Chuan-Xi Zhang, Jian-Ping Chen* and \\ Qianzhuo Mao*
}

State Key Laboratory for Managing Biotic and Chemical Threats to the Quality and Safety of Agro-Products, Key Laboratory of Biotechnology in Plant Protection of Ministry of Agriculture and Zhejiang Province, Institute of Plant Virology, Ningbo

University, Ningbo, China

\section{OPEN ACCESS}

Edited by:

Yongjun Wei,

Zhengzhou University, China

Reviewed by:

Dorith Rotenberg,

North Carolina State University,

United States

Ruobing Guan,

Key Laboratory of Insect

Developmental and Evolutionary

Biology, Institute of Plant Physiology

and Ecology, Shanghai Institutes

for Biological Sciences, Chinese Academy of Sciences (CAS), China

Xifeng Wang,

State Key Laboratory for Biology of Plant Diseases and Insect Pests, Institute of Plant Protection, Chinese Academy of Agricultural Sciences

(CAAS), China

${ }^{*}$ Correspondence: Jian-Ping Chen

jianpingchen@nbu.edu.cn Qianzhuo Mao

hermione9@163.com

Specialty section:

This article was submitted to Microbial Symbioses,

a section of the journal

Frontiers in Microbiology

Received: 30 October 2021

Accepted: 03 January 2022

Published: 27 January 2022

Citation:

Wu W, Shan H-W, Li J-M,

Zhang $C-X$, Chen J-P and Mao Q (2022) Roles of Bacterial Symbionts in

Transmission of Plant Virus by

Hemipteran Vectors.

Front. Microbiol. 13:805352.

doi: 10.3389/fmicb.2022.805352
The majority of plant viruses are transmitted by hemipteran insects. Bacterial symbionts in hemipteran hosts have a significant impact on the host life, physiology and ecology. Recently, the involvement of bacterial symbionts in hemipteran vector-virus and vectorplant interactions has been documented. Thus, the exploitation and manipulation of bacterial symbionts have great potential for plant viral disease control. Herein, we review the studies performed on the impact of symbiotic bacteria on plant virus transmission, including insect-bacterial symbiont associations, the role of these bacterial symbionts in viral acquisition, stability and release during viral circulation in insect bodies, and in viral vertical transmission. Besides, we prospect further studies aimed to understand tripartite interactions of the virus-symbiotic microorganisms-insect vector.

Keywords: plant virus, insect vector, bacterial symbionts, horizontal transmission, vertical transmission

\section{INTRODUCTION}

Insect-borne viruses have been associated with significant global challenges in humans, animals, and plants. Most plant viruses depend on insect vectors for their survival and transmission. Insects transmit plant viruses via three principal modes, non-persistent, semi-persistent, and persistent. This is based on the length of the period the vector can harbor infectious particles, which ranges from minutes to hours (non-persistent), days (semi-persistent) as well as for a lifetime and even inheritance by insect progeny (persistent). For non-persistent and semi-persistent viruses, viral particles are mainly retained by the vector in the stylet (food canal) or foregut, respectively ( $\mathrm{Ng}$ and Falk, 2006; Hogenhout et al., 2008). Most persistent plant viruses are transmitted by Hemiptera insects (including aphids, whiteflies, leafhoppers, and planthoppers) (Hogenhout et al., 2008; Gray et al., 2014; Jones and Naidu, 2019). During insect sucking, persistent viruses are taken up together with the plant sap. Subsequently, they infect gut epithelial cells, are released into the hemocoel, invade hemocytes, the salivary glands, and other tissues/organs, including nervous systems and reproductive systems (Hogenhout et al., 2008; Wei and Li, 2016; Wilson et al., 2020). The vector insects transmit the plant viruses to healthy plant hosts during the course of sucking plant sap (Blanc et al., 2014; Wei and Li, 2016; Wang and Blanc, 2021). Viruses that replicate in insect bodies are referred to as persistent propagative viruses, while those that do not are referred to as persistent circulative viruses (Hogenhout et al., 2008). Often, propagative viruses infect reproductive systems and can be vertically transmitted between generations of insect vectors (Wei and Li, 2016; Wilson et al., 2020).

Viral dissemination in insect bodies is highly associated with vector competency of viral transmissions. Most studies on transmission mechanisms are based on virus-insect protein interactions as well as host and vector manipulations (Wei and Li, 2016; Wang and Blanc, 2021; 
$\mathrm{Xu}$ et al., 2021). As in mammals and other eucaryotes, insects are inhabited by various symbiont microorganisms and the insect health and basic biology are influenced and modulated by them, including nutritional metabolism, reproduction, and pathogen defense (Douglas, 2011; Bennett and Moran, 2013; Newell and Douglas, 2014). Increasing evidence reveals that symbiotic interactions between insects and microorganisms can also affect the transmission of plant viruses by insect vectors (Moran et al., 2005; Werren et al., 2008). Therefore, symbiotic microbes of insects are also involved in tripartite interactions among plant virus, insect vectors and plant host. Through direct and/or indirect mechanisms, such as immune status regulation, modulation of physical barriers on the intestinal epithelium, or the release microbe-derived components/metabolites, symbionts play intricate roles in regulation of insect vector permissiveness to viruses (Cirimotich et al., 2011; Shane et al., 2018; Wu P. et al., 2019; Ma et al., 2021). Therefore, we review recent studies on the significance of symbiotic microorganisms of insect vectors in regulation of plant virus transmission to elucidate on the multilayered virus-vector-microbial symbiont interactions.

\section{ASSOCIATIONS BETWEEN INSECTS AND THEIR BACTERIAL SYMBIONTS}

Various insects live in intimate symbiotic associations with microorganisms, which allows insects to adapt to various ecological environments (Moran, 2007; Duron and Hurst, 2013). Insect viability and mobility, which can be influenced by symbiotic organisms, impacts their abilities as viral vectors. Microbial symbionts provide essential nutrients for insect hosts and regulate the development, reproduction, metabolism, immunity, protection from antagonists, degradation of toxins, as well as host adaptation to a given environment (Hansen and Moran, 2014; Gao et al., 2020). Based on the degree of interdependence between symbionts and their hosts, they can be divided into obligate (primary) and facultative (secondary) symbionts (Buchner, 1965), between which, there are no clear distinctions. This means that, under special circumstances, facultative symbionts can become obligate (Latorre and Manzano-Marin, 2017).

Many insects feed on poor or unbalanced food sources, including sap-sucking hemipteran insects (including aphids, psyllids, planthoppers, leafhoppers, and whiteflies), bloodfeeding tsetse flies, cockroaches, weevils, and certain generas of ants (Hansen and Moran, 2014; Rio et al., 2016). Therefore, in most cases, obligate symbionts can supply essential nutrients to these insects (Douglas, 2011). Often, these symbionts exist within specialized, enlarged insect cells referred to as mycetocytes or bacteriocytes, which are integrated into large organs termed mycetomes or bacteriomes. They exhibit a complete dependence on hosts to survive and they cannot be artificially cultured in vitro. The bacteriome consists of body fat cells, gut-wall cells, or highly specialized cells that are developmentally determined in the embryonic stage, varying among host groups (Buchner, 1965). In addition, obligate symbionts are strictly vertically transmitted from their mothers to offsprings, usually by infecting oocytes or embryos through various mechanisms (Miura et al., 2003; Gottlieb et al., 2008; Sacchi et al., 2008), or by being encased in "symbiotic shuttles", that is, symbiont containing capsules that are deposited by females under egg mass (Hosokawa et al., 2007). Consequently, obligate symbionts exhibit hallmarks of long-term co-evolutions with their insect hosts, such as extreme genome reductions (Moran and Bennett, 2014). With regards to facultative symbionts, they may be involved in a broad variety of roles when compared to obligate symbionts, and provide ecological benefits for insect hosts, including adaptation to host plants, body color regulation, heat tolerance, manipulation of host reproduction, pathogenic transmission, defense against natural enemies, and insecticide resistance (Oliver et al., 2003; Tsuchida et al., 2004, 2010; Burke et al., 2010; Hansen and Moran, 2014). Besides, facultative symbionts are distributed in various tissues and cell types of insect vectors and can be transmitted via both vertical and horizontal mechanisms (Moran et al., 2008; Moran and Bennett, 2014).

Plant sap-feeding hemipteran insects, such as aphids, whiteflies, leafhoppers and planthoppers, are the most important agricultural pests and serve as vectors for phytopathogenic viruses and bacteria (Hogenhout et al., 2008; Wei and Li, 2016; Wang and Blanc, 2021; Xu et al., 2021). Among them, aphids are polyphagous and transmit over 100 plant viruses (Hogenhout et al., 2008; Chen Y.Z. et al., 2020). Due to the diversity of aphid-associated symbiont communities, they are probably the best model systems for studies on symbiont-host interactions. Nearly all aphids are infected with the obligate endosymbiont, Buchnera aphidicola (hereafter referred to as Buchnera), which is housed inside bacteriocytes and is strictly vertically transmitted from the mother to offsprings (Dedryver et al., 2010). As an endosymbiont, Buchnera provides essential nutrients and vitamins to the aphid host, which cannot be obtained from the diet or from other symbionts (Hansen and Moran, 2011). Through co-inhabitation with Buchnera, aphids may also harbor one or several facultative symbionts, which provide ecological benefits to hosts, including defensive behaviors (Hamiltonella defensa), reproduction (Wolbachia), body color (Rickettsiella), host plant fitness (Regiella insecticola), heat shock enhancement, parasitoid as well as pathogenic resistance (Serratia symbiotica, $H$. defensa, and R. insecticola) (Guo et al., 2017).

The whitefly, Bemisia tabaci, which can feed on over 600 plants species, including vegetables, fibers, and ornamental crops, is one of the most destructive insect pests. It is a natural vector of persistently transmitted begomoviruses (family Geminiviridae) as well as some semi-persistently and non-persistently transmitted plant viruses (Brown and Czosnek, 2002; Wang and Blanc, 2021). Portiera aleyrodidarum (hereafter referred to as Portiera), the obligate endosymbiont for all whitefly species, is localized in the bacteriome, which comprises several bacteriocytes. It provides essential amino acids, carotenoids, and other metabolites that are scanty in a phloem sap diet to its insect host (Thao and Baumann, 2004; Sloan and Moran, 2012). In whiteflies, Portiera is transmitted to progenies through a unique mechanism in which intact bacteriocytes migrate to the ovaries and enter eggs (Luan et al., 2016). In addition to Portiera, whitefly species are associated with seven facultative endosymbionts; Arsenophonus, 


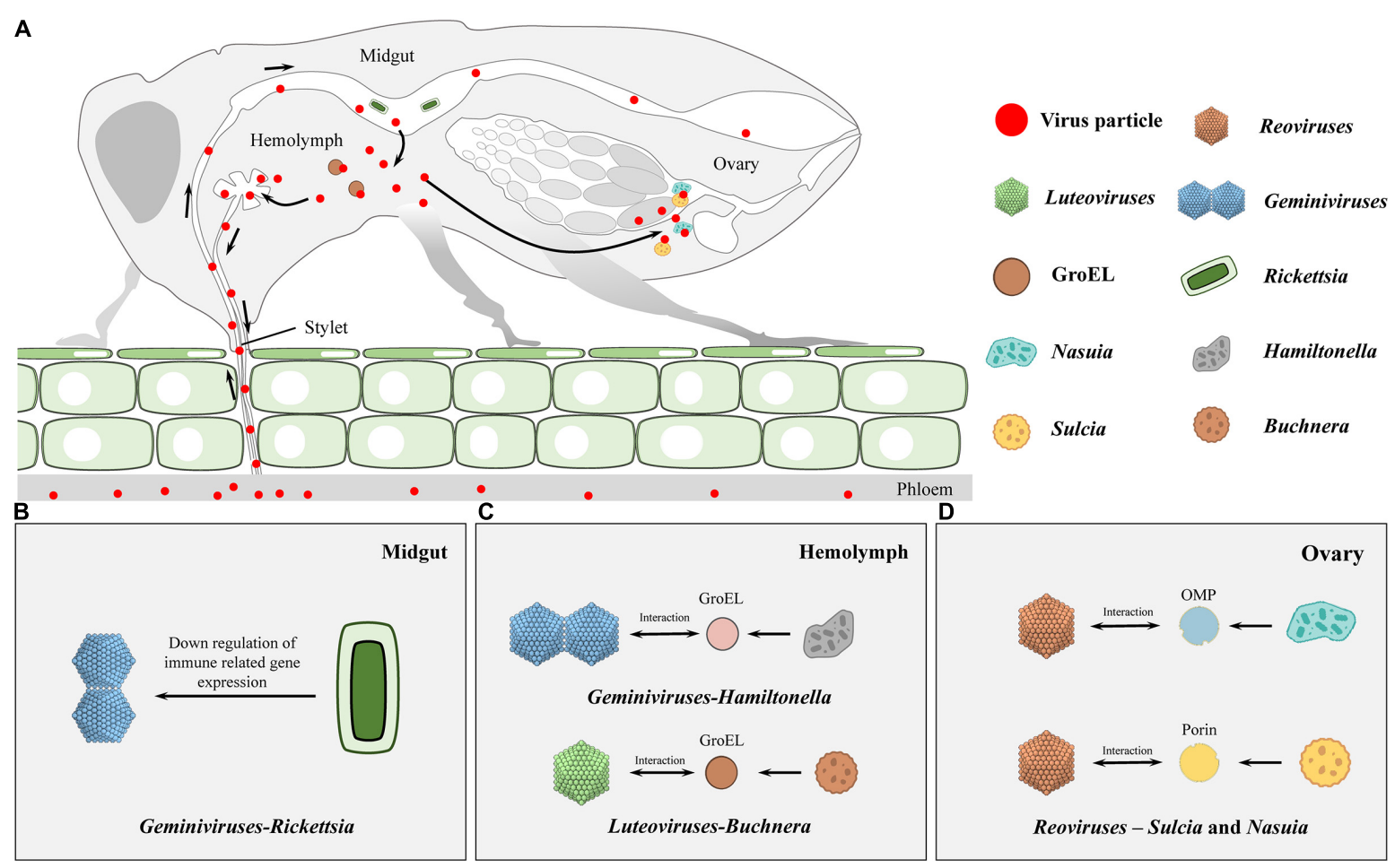

FIGURE 1 | Schematic diagram on infection routes of persistent plant viruses in insect vector. (A) During feeding, viral particles are sucked up together with plant sap proteins and ingested into the gut lumen by the insect vectors. Subsequently, the ingested virions initially infect the intestinal epithelium and transfer across the midgut cellular barriers to the hemolymph. Finally, virions enter into salivary glands to be horizontally transmitted to healthy plants or transfer into the reproductive system, thus being vertically transmitted to offspring. (B,C) In horizontal transmission, Rickettsia in the midgut lumen can benefit geminivirus acquisition, retention, and transmission in the insect (B). Here, it should be noticed that GroEL-begomovirus/-luteovirus interaction is essential for the stability of the virus in hemolymph, otherwise the insect immune system may recognize and degrade these foreign invaders (C). (D) During the process of vertical transmission, Reovirus virions migrate to the ovaries and enter the eggs by hitchhiking on the envelopes of Sulcia and Nasuia, and they benefit from the vertical transmission routes taken by the two obligate bacterial symbiont partners in females.

Cardinium, Fritschea, Hamiltonella, Hemipteriphilus, Rickettsia, and Wolbachia (Zchori-Fein and Brown, 2002; Nirgianaki et al., 2003; Weeks et al., 2003; Everett et al., 2005; Gottlieb et al., 2006; Bing et al., 2013).

Symbioses in Auchenorrhyncha (Hemiptera: suborder), such as leafhoppers, treehoppers, cicadas, planthoppers, and spittlebugs, are ancient and complicated. The obligate symbiont, Sulcia muelleri (hereafter referred to as Sulcia), and one or two coobligate betaproteobacterial symbionts are associated with many hosts (Buchner, 1965; Bennett and Moran, 2013). Normally, Sulcia synthesizes a set of seven or eight essential amino acids, while a co-obligate betaproteobacterial symbiont synthesizes the two or three remaining essential amino acids (Bennett and Moran, 2013). Sulcia and the co-obligate betaproteobacterial symbionts are confined to bacteriomes located in host abdomens (Buchner, 1965). In female adults, simultaneously, Sulcia and the co-obligate betaproteobacterial symbiont enter same follicular epithelial cells surrounding posterior poles of oocytes and accumulate in oocytes to form a characteristic "symbiont ball” (Pyka-Fosciak and Szklarzewicz, 2003; Michalik et al., 2013; Szklarzewicz et al., 2016). In the leafhopper, some coobligate betaproteobacterial symbionts are able to live inside cytoplasms of Sulcia to ensure simultaneous transovarial transmissions in generations of insects (Michalik et al., 2013, 2014; Kobiałka et al., 2016).

Due to the loss of co-obligate betaproteobacterial symbionts in some Auchenorrhyncha species, they have been replaced by novel co-symbionts, such as gammaproteobacteria or yeastlike symbionts (Noda, 1977; Szklarzewicz et al., 2020). For instance, the obligate symbiont, Sulcia, in planthoppers was lost and replaced by the yeast-like symbiont (YLS) to provide essential amino acids (Sasaki et al., 1996). However, YLS genomes do not have complete vitamin B synthetic genes, therefore, the facultative symbiont, Wolbachia, is required for vitamin B synthesis in the host (Ju et al., 2020). In insects, Wolbachia is the most abundant endosymbiont and is best known for altering host reproductive biology to enhance the spread of infections across generations (Stevens et al., 2001).

\section{EFFECTS OF BACTERIAL SYMBIONTS ON PLANT VIRUS CIRCULATION IN INSECT BODIES}

In persistent transmissions, plant viruses move through insect bodies and are horizontally transmitted from infected plant hosts 
to healthy hosts. Suspended viral particles in plant saps are usually taken up by insects through ingestion, they circulate in the gut, the hemolymph and salivary glands, and are finally released into saliva for transmission (Figure 1A; Hogenhout et al., 2008; Wei and Li, 2016; Wang and Blanc, 2021). Within insects, viruses encounter multiple physical and immune barriers, and previous studies often interpret these mechanisms in terms of protein interactions (Jia et al., 2018; Wilson et al., 2020). In fact, symbiotic bacteria influence multiple insect physiologies, such as nutrition, metabolism, reproduction as well as immunity, and can maintain homeostasis within insects through various immune mechanisms (Hansen and Moran, 2014; Gao et al., 2020). Moreover, increasing evidence has revealed that these endosymbionts play intricate roles in modulation of vector susceptibility to viruses and their transmission through direct or indirect mechanisms. Therefore, we elucidated on the roles of symbionts during the cycle of plant viruses in insect bodies.

\section{Bacterial Symbionts Regulating Viral Acquisition by Insect Vectors}

When insect vectors feed on virus-infected plants, the intestinal tract is the first viral-entry site of persistent viruses, therefore, it is the principal determinant for viral transmission by insects (Hogenhout et al., 2008; Wei and Li, 2016; Wilson et al., 2020). Gut commensal microbiome may regulate host defenses against viral infections of gut epithelial cells (Yin et al., 2020), however, the relationship between intestinal symbionts and plant viruses during viral acquisition by insect vectors has not been fully established.

Various studies have reported the involvement of endosymbionts in acquisitions of plant viruses. In the B. tabaci whitefly, nearly all facultative symbionts are co-localized with obligate endosymbionts inside bacteriocytes, ensuring vertical transition (Zchori-Fein and Brown, 2002; Nirgianaki et al., 2003; Weeks et al., 2003; Thao and Baumann, 2004; Everett et al., 2005; Gottlieb et al., 2006; Sloan and Moran, 2012; Bing et al., 2013). On the contrary, Rickettsia exists outside bacteriocytes, infects all insect organs, and replicates to high levels in the gut, hemolymph, and salivary glands (Gottlieb et al., 2008; Brumin et al., 2012). Kliot et al. (2014) established two isofemale whitefly strains from an inbred B biotype strain ( 300 generations): Rickettsia infected (Rick+) and the Rickettsia non-infected (Rick-). They showed that Rickettsia infections enhance tomato yellow leaf curl virus (TYLCV) acquisition, retention, and transmission by insects (Table 1). The acquisition of TYLCV massively down-regulated immune system gene expressions in the Rick+ population, while in the Rick- population, the virus massively activated immune-related gene expressions (Figure 1B; Kliot et al., 2019). Lei et al. (2021) documented that interactions between the rickettsial secretory protein, BtR242, and protein coat of the cotton leaf curl Multan virus (CLCuMuV), was beneficial in CLCuMuV transmission by whiteflies (Table 1). Moreover, vitellogenin $(\mathrm{Vg})$ levels in the Rick+ population was more than twofold higher than that of the Rick-population. Biologically, $\mathrm{Vg}$ facilitates TYLCV movement across the midgut barrier of its insect vector, B. tabaci (He et al., 2021). It has been reported that gut microbiota are not involved in persistent plant virus transmissions by insect vectors, for instance, gut microbiota of thrips larvae did not influence TSWV transmissions (Table 1; De Vries et al., 2012); Wheat dwarf virus (WDV) altered the gut microbiota through a dynamic and reversible manner, while viral transmission was not affected by gut microbiota diversity and abundance in the leafhopper (Table 1; Wang et al., 2019).

Given that most gut symbiotic microorganisms are obtained from food, the diversity of intestinal symbiotic microorganisms in sap-feeding insects is significantly low due to low microbial contents in plant sap (Jing et al., 2014). This is a major limitation of studies on direct interactions between intestinal microbes and plant viruses in insect gut cell infections. In arboviruses, gut microbiota regulate viral infections in gut epithelial cells by modulating gut immune responses, altering the physical status, or by directly utilizing microbiota-derived products (Wu P. et al., 2019; Ma et al., 2021). For instance, Proteus sp., which is a mosquito intestinal symbiotic bacteria, suppresses dengue virus (DENV) infection by enhancing the expression levels of antimicrobial peptides in gut epithelial cells (Ramirez et al., 2012), while another gut commensal, Serratia marcescens, facilitates arboviral infections by secreting the SmEnhancin protein, which digests gut membrane-bound mucins, thereby enhancing viral dissemination in mosquitoes ( $\mathrm{Wu}$ P. et al., 2019). The gut commensal, Chromobacterium sp., secretes an aminopeptidase that is able to degrade the DENV envelope protein, preventing their attachment and infection of host cells (Saraiva et al., 2018).

\section{Bacterial Symbionts Contributing to the Stability of Plant Viruses in Vector Hemolymph}

The insect hemolymph, which is critical in persistent viral transmissions by insect vectors, can be used as a bridge to the salivary glands (Liu et al., 2015; Chen X. et al., 2020). Besides, it is well-defended by the immune system, which can effectively remove microorganisms (such as bacteria, fungi, and viruses) (Lavine and Strand, 2002; Blow and Douglas, 2019). Even though obligate symbionts have long-term coevolutions with their insect hosts, they can only exist within specialized cells (mycetocytes or bacteriocytes) to escape the immune system (Gross et al., 2009). After viral particles are released from the midgut to the hemolymph, they can be recognized, targeted and cleared by the host immune system. Therefore, survival of virions within the hemolymph is vital for systemic dissemination of persistent viruses before entry into salivary glands (Liu et al., 2015; Chen X. et al., 2020).

Van den Heuvel et al. (1994) reported that chaperone proteins of endosymbionts may be involved in maintenance of plant viruses in the hemolymph. They used a virus overlay assay to search for proteins that interacted with the Potato leafroll virus (PLRV) in the green peach aphid Myzus persicae Sulzer (Homoptera: Aphididae) and revealed that PLRV binds the symbionin expressed by the obligate endosymbiont of M. persicae, Buchnera (Table 1). Administration of antibiotics to aphids was associated with the absence of symbionin in the 
TABLE 1 | Summary of the interactions of insect endosymbionts with plant viruses demonstrated by in vitro or in vivo experiments.

\begin{tabular}{|c|c|c|c|c|c|}
\hline Insect & Endosymbiont & $\begin{array}{l}\text { Endosymbiont } \\
\text { product }\end{array}$ & Virus & Effect on transmission & References \\
\hline Myzus persicae & Unspecified & Undetermined & Potato leaf roll virus & $\begin{array}{l}\text { Endosymbiotic bacteria play a crucial role in } \\
\text { determining the persistent nature of PLRV in the aphid } \\
\text { hemolymph. }\end{array}$ & $\begin{array}{l}\text { Van den Heuvel } \\
\text { et al., } 1994\end{array}$ \\
\hline M. persicae & Unspecified & $\begin{array}{l}\text { Symbionine (GroEL } \\
\text { homolog) }\end{array}$ & Potato leaf roll virus & $\begin{array}{l}\text { The absence of GroEL homolog in the hemolymph of } \\
\text { aphids after treated with antibiotics leads to virus } \\
\text { degradation and concomitant loss of infectivity. }\end{array}$ & $\begin{array}{l}\text { Hogenhout } \\
\text { et al., } 1996\end{array}$ \\
\hline $\begin{array}{l}\text { R. padi Sitobion } \\
\text { avenae }\end{array}$ & Unspecified & $\begin{array}{l}\text { SymL (GroEL } \\
\text { homolog) }\end{array}$ & $\begin{array}{l}\text { Barley yellow dwarf } \\
\text { virus }\end{array}$ & Endosymbiotic SymL interacted with BYDV RTD. & $\begin{array}{l}\text { Filichkin et al., } \\
1997\end{array}$ \\
\hline $\begin{array}{l}\text { M. persicae } \\
\text { Acyrthosiphon } \\
\text { pisum } \\
\text { Rhopalosiphum } \\
\text { padi }\end{array}$ & Buchnera & GroEL & $\begin{array}{l}\text { Beet western } \\
\text { yellows virus, Beet } \\
\text { mild yellowing virus, } \\
\text { Potato leaf roll } \\
\text { virus, Cucurbit } \\
\text { aphid-borne } \\
\text { yellows virus, Bean } \\
\text { leafroll virus } \\
\text { Soybean dwarf } \\
\text { virus Pea enation } \\
\text { mosaic virus }\end{array}$ & $\begin{array}{l}\text { The N-terminal region of the luteovirus RTD determines } \\
\text { virus binding to Buchnera GroEL and is essential for the } \\
\text { stability of virions in hemolymph. }\end{array}$ & $\begin{array}{l}\text { van den Heuvel } \\
\text { et al., } 1997\end{array}$ \\
\hline M. persicae & Buchnera & GroEL & Potato leaf roll virus & $\begin{array}{l}\text { The interaction site between PLRV and Buchnera } \\
\text { GroEL is located in the equatorial domain. }\end{array}$ & $\begin{array}{l}\text { Hogenhout } \\
\text { et al., } 1998\end{array}$ \\
\hline Bemisia tabaciis & Unspecified & GroEL homolog & $\begin{array}{l}\text { Tomato yellow leaf } \\
\text { curl virus }\end{array}$ & $\begin{array}{l}\text { No TYLCV viral DNA was detected in the hemolymph of } \\
\text { whiteflies fed with anti-GroEL antibodies prior to virus } \\
\text { acquisition. }\end{array}$ & $\begin{array}{l}\text { Morin et al., } \\
1999\end{array}$ \\
\hline A. pisum & Undetermined & Undetermined & $\begin{array}{l}\text { Pea enation mosaic } \\
\text { virus }\end{array}$ & $\begin{array}{l}\text { The RTD is not necessary for stability of PEMV in the } \\
\text { aphid hemolymph. }\end{array}$ & Liu et al., 2009 \\
\hline A. pisum R. padi & Buchnera & GroEL & $\begin{array}{l}\text { Barley yellow dwarf } \\
\text { virus }\end{array}$ & $\begin{array}{l}\text { GroEL was detected in bacteriocyte, but not in the } \\
\text { aphid hemolymph, fat body or gut. }\end{array}$ & $\begin{array}{l}\text { Bouvaine et al., } \\
2011\end{array}$ \\
\hline $\begin{array}{l}\text { Schizaphis } \\
\text { graminum }\end{array}$ & Buchnera & Undetermined & $\begin{array}{l}\text { Cereal yellow dwarf } \\
\text { virus }\end{array}$ & $\begin{array}{l}\text { The genotype of Buchnera correlates with the ability to } \\
\text { efficiently transmit CYDV by aphid. }\end{array}$ & $\begin{array}{l}\text { Cilia et al., } \\
2011\end{array}$ \\
\hline B. tabaciis & Hamiltonella & GroEL & $\begin{array}{l}\text { Tomato yellow leaf } \\
\text { curl virus }\end{array}$ & $\begin{array}{l}\text { The GroEL protein produced by Hamiltonella facilitates } \\
\text { TYLCV transmission. }\end{array}$ & $\begin{array}{l}\text { Gottlieb et al., } \\
2010\end{array}$ \\
\hline Bemisia tabaci & Arsenophonus & GroEL & $\begin{array}{l}\text { Cotton leaf curl } \\
\text { virus }\end{array}$ & $\begin{array}{l}\text { Arsenophonus involve in the transmission of CLCuV in } \\
\text { whitefly. }\end{array}$ & $\begin{array}{l}\text { Rana et al., } \\
2012\end{array}$ \\
\hline $\begin{array}{l}\text { Frankliniella } \\
\text { occidentalis }\end{array}$ & Erwinia sp. & Unspecified & $\begin{array}{l}\text { Tomato spotted wilt } \\
\text { virus }\end{array}$ & $\begin{array}{l}\text { TSWV transmission is not affected by the number of the } \\
\text { symbiotic bacteria Erwinia sp. present in the gut of } \\
\text { thrips larvae. }\end{array}$ & $\begin{array}{l}\text { De Vries et al., } \\
2012\end{array}$ \\
\hline B. tabaciis & Hamiltonella & Unspecified & $\begin{array}{l}\text { Tomato yellow leaf } \\
\text { curl virus }\end{array}$ & $\begin{array}{l}\text { Hamiltonella is closely associated with the acquisition, } \\
\text { retention and transmission efficiency of TYLCV by the } \\
\text { whitefly. }\end{array}$ & Su et al., 2013 \\
\hline Bemisia tabaci & Rickettsia & Undetermined & $\begin{array}{l}\text { Tomato yellow leaf } \\
\text { curl virus }\end{array}$ & $\begin{array}{l}\text { Rickettsia increases TYLCV transmission efficacy by } \\
\text { infecting the midgut. }\end{array}$ & $\begin{array}{l}\text { Kliot et al., } \\
2014\end{array}$ \\
\hline $\begin{array}{l}\text { Nephotettix } \\
\text { cincticeps }\end{array}$ & Sulcia & $\begin{array}{l}\text { Out membrane } \\
\text { protein }\end{array}$ & Rice dwarf virus & Sulcia supporting RDV transfer to the next generation. & Jia et al., 2017 \\
\hline B. tabaciis & Hamiltonella & Unspecified & $\begin{array}{l}\text { Cowpea mild } \\
\text { mottle virus, Bean } \\
\text { golden mosaic } \\
\text { virus, Tomato } \\
\text { chlorosis virus }\end{array}$ & $\begin{array}{l}\text { Hamiltonella increased the transmission efficiency of } \\
\text { begomovirus by the whitefly. }\end{array}$ & $\begin{array}{l}\text { Bello et al., } \\
2019\end{array}$ \\
\hline Bemisia tabaci & Rickettsia & Undetermined & $\begin{array}{l}\text { Tomato yellow leaf } \\
\text { curl virus }\end{array}$ & $\begin{array}{l}\text { Rickettsia down-regulates of whitefly immunity genes to } \\
\text { increase the ability of whitefly to acquire, retain and } \\
\text { transmit TYLCV. }\end{array}$ & $\begin{array}{l}\text { Kliot et al., } \\
2019\end{array}$ \\
\hline $\begin{array}{l}\text { Nephotettix } \\
\text { cincticeps }\end{array}$ & Nasuia & Prion & Rice dwarf virus & Nasuia supporting RDV transfer to the next generation. & $\begin{array}{l}\text { Wu W. et al., } \\
2019\end{array}$ \\
\hline $\begin{array}{l}\text { Psammotettix } \\
\text { alienus }\end{array}$ & Unspecified & Unspecified & Wheat dwarf virus & $\begin{array}{l}\text { WDV changes the gut microbiota by a dynamic and } \\
\text { reversible manner, while the virus transmission was not } \\
\text { affected by the diversity and abundance of gut } \\
\text { microbiota in leafhopper. }\end{array}$ & $\begin{array}{l}\text { Wang et al., } \\
2019\end{array}$ \\
\hline
\end{tabular}


TABLE 1 | (Continued)

\begin{tabular}{|c|c|c|c|c|c|}
\hline Insect & Endosymbiont & $\begin{array}{l}\text { Endosymbiont } \\
\text { product }\end{array}$ & Virus & Effect on transmission & References \\
\hline $\begin{array}{l}\text { Nilaparvata lugens } \\
\text { Laodelphax } \\
\text { striatellus }\end{array}$ & Wolbachia & Unspecified & $\begin{array}{l}\text { Rice ragged stunt } \\
\text { virus }\end{array}$ & $\begin{array}{l}\text { The Wolbachia strain wStri (Isolated from the small } \\
\text { brown planthopper, Laodelphax striatellus) has been } \\
\text { stably introduced into brown planthopper, Nilaparvata } \\
\text { lugens and shown to inhibited infection and } \\
\text { transmission of Rice ragged stunt virus (RRSV) and } \\
\text { mitigated virus-induced symptoms in rice plants. }\end{array}$ & $\begin{array}{l}\text { Gong et al., } \\
2020\end{array}$ \\
\hline Bemisia tabaci & Rickettsia & Unspecified & $\begin{array}{l}\text { Cotton leaf curl } \\
\text { multan virus }\end{array}$ & $\begin{array}{l}\text { Rickettsia enhances the transmission efficiency of the } \\
\text { CLCuMuV by whitefly. }\end{array}$ & Lei et al., 2021 \\
\hline
\end{tabular}

hemolymph, which led to viral degradation, loss of infection, and a $70 \%$ reduction in transmission efficiencies (Table 1; Van den Heuvel et al., 1994; Hogenhout et al., 1996). Symbionin, which has a high homology with the Escherichia coli heat shock protein, GroEL, is a chaperone that is highly conserved from bacteria to all multicellular life forms and is generally composed of 14-18 subunits arranged in two rings. It enhances proper folding of complex, multidomain proteins and is involved in the maintenance of protein homeostasis (Piana and Shaw, 2018). Studies involving aphids and luteoviruses revealed that all luteoviruses bind GroEL proteins (with different affinities), while purified luteovirus particles contain a major $22-\mathrm{kDa}$ coat protein (CP) and less amounts of an approximately $54-\mathrm{kDa}$ readthrough protein (RTD), expressed by translational readthrough of the $\mathrm{CP}$ into the adjacent open reading frame. Beet western yellow luteovirus (BWYV) mutants, lacking RTD, did not bind Buchnera GroEL (Table 1). However, mutants with deletions only at the C-terminal of RTD bound as efficiently as wild-type BWYV. These findings imply that the conserved N-terminal of RTD is part of the luteovirus capsid that is required for binding of GroEL to virions (Figure 1C; Filichkin et al., 1997; van den Heuvel et al., 1997). In vitro interaction studies showed that PLRV binds the equatorial domain of Buchnera GroEL (Hogenhout et al., 1998).

The involvement of GroEL in luteovirus transmission has not been conclusively determined. Liu et al. reported that Pea enation mosaic virus (PEMV) mutants devoid of the readthrough domain (RTD) exhibited the same stability as wild-type viruses in aphid hemolymphs (Table 1). This indicates that RTD is not necessary for PEMV stability in aphid hemolymph (Liu et al., 2009). In addition, through immunoblotting and immunocytochemistry, Bouvaine et al. (2011) reported that GroEL was restricted to the bacteriocyte and was never detected in aphid hemolymph, fat body or gut (Table 1). Therefore, Buchnera GroEL was not available to interact with luteoviruses in vivo (Bouvaine et al., 2011). Furthermore, Bouvaine et al. (2011) considered that specific detection of GroEL in the hemolymph is depended on the method used for aphid dissection. In the hemolymph, GroEL can be detected if cornicle amputation is used for hemolymph collection, but it is never detected when leg amputation is performed to obtain hemolymph (Bouvaine et al., 2011). Through proteomics and genetics experiments, Cilia et al. (2011) evaluated the linkage between Buchnera genotypes and the ability to transmit Cereal yellow dwarf virus-RPV (CYDVRPV) (Table 1). They proved that one Buchnera genotype is required for viral transmission (Cilia et al., 2011). Taken together, these studies do not prove or disapprove that Buchnera GroEL contributes to the stability of luteoviruses in aphid hemolymph. Therefore, the mechanism through which GroEL protects the virus during hemolymph translocation may not be the same for all luteoviruses.

Similar to aphid-transmitted luteoviruses, geminivirus is transmitted in a circulative manner by whiteflies. A GroEL homolog produced by Hamiltonella, a facultative endosymbiont of the whitefly, showed $80 \%$ homology with that from different aphid species and GroEL from E. coli. Feeding the antiBuchnera GroEL antiserum to $B$. tabaci whitefly before viral acquisition inhibited TYLCV transmission by more than $80 \%$ (Figure 1C, Table 1; Morin et al., 1999). In addition, the GroEL expressed by Hamiltonella, a facultative endosymbiont of B. tabaci, exhibited $80 \%$ homology with Buchnera GroEL, and specifically interacted with the TYLCY CP (Gottlieb et al., 2010). $\mathrm{Su}$ et al. (2013) cultured two isofemale strains [Hamiltonella infected $(\mathrm{H}+)$ and Hamiltonella non-infected $(\mathrm{H}-)]$ from a same genetic background insect strain via antibiotic treatment and introgression. Through further studies, they found that whiteflies harboring Hamiltonella were suitable for TYLCV acquisition, retention, and spread (Table 1). Moreover, the abundance of Hamiltonella on whiteflies has been associated with the transmission efficiency of non-circulative viruses (Table 1; Bello et al., 2019). The GroEL protein of Arsenophonus (another facultative symbiotic bacterium of whitefly) was also found to interact with the Cotton leaf curl virus in vitro and in vivo (Table 1; Rana et al., 2012). In summary, GroEL-plant virus interactions are not restricted to begomoviruses, and they may be applicable to all whitefly transmitted plant viruses.

\section{Bacterial Symbionts Influence Plant Virus Infections}

Escape from insect salivary glands and injection into plant cells with saliva during insect feeding are crucial steps in persistent viral transmission (Hogenhout et al., 2008; Wei and Li, 2016; Wang and Blanc, 2021). Insect salivary glands consist of principal salivary glands and accessory salivary glands, while salivary gland cells are filled with abundant apical plasma membrane lining cavities, where saliva is stored. Plant viruses escape across membrane barriers through specific virus-insect protein interactions (Wei and Li, 2016; Mao et al., 2017), and it has not been determined whether symbionts play a role. Nevertheless, apart from overcoming salivary gland barriers, the stability and 
infective abilities of viral particles during salivating into plant cells, as well as insect feeding behaviors are greatly involved in the success of inoculation.

The significance of endosymbiotic GroEL in plant virus transmission has been inconclusively discussed. GroEL can bind viruses in vivo as well as in vitro, and many plant circulative viruses interact with it to avoid destruction in hemolymphs of their insect vectors, such as luteoviruses and Buchnera GroEL in aphids, as discussed above. Buchnera GroEL has also been detected in saliva (Table 1; Chaudhary et al., 2014), indicating that it plays a role (such as aiding viral survival in saliva) during plant infections by viruses. Nevertheless, transgenic Nicotiana benthamiana plants expressing GroEL exhibited tolerance to TYLCV and cucumber mosaic virus (CMV) that showed interactions with GroEL, but not to grapevine virus A (GAV) or tobacco mosaic virus (TMV) that did not show any interactions (Table 1; Edelbaum et al., 2009). The binding to GroEL by viruses in plant sap inhibits them from infecting plants. Besides, the delivery of GroEL into tomato and Arabidopsis plants can trigger plant defense systems, pattern-triggered immunity (PTI), which is detrimental to aphid fecundity (Chaudhary et al., 2014). Therefore, expressions of GroEL in plants has the potential for controlling some viral diseases and their insect vectors. These studies suggest that bacterial symbionts in insects may impact plant infection by exerting indirect effects through the modulation of plant defense pathways.

In their study on CMV transmission by the green peach aphid, M. persicae, Shi et al. (2021) reported that CMV can switch the insect vector's feeding preference by affecting the abundance of the obligate endosymbiont, $B$. aphidicola. However, as a nonpersistent virus that is transmitted by aphids, through its $\mathrm{CP}$, $\mathrm{CMV}$ only binds the stylet of insects. It has been documented that B. aphidicola, an aphid endosymbiont, influences herbivore behaviors by modulating plant volatile profiles, implying that CMV infections reduce the abundance of $B$. aphidicola in aphids, which has been associated with a preference shift in aphids from infected to healthy plants (Shi et al., 2021). It is revealed that the symbiotic bacteria affect feeding tropisms and feeding behaviors of insects and influences plant infections by viruses (Frago et al., 2012; Simon et al., 2017; Khan et al., 2019; Noman et al., 2020).

\section{THE ROLES OF BACTERIAL SYMBIONTS IN VERTICAL TRANSMISSIONS OF PLANT VIRUSES BY INSECTS}

Apart from horizontal viral transmissions between host plants and insect vectors, some persistent viruses can be vertically transmitted from virus-infected parents to their offsprings through maternal or paternal transmissions (Hogenhout et al., 2008; Wei and Li, 2016; Wang and Blanc, 2021). Vertical viral transmissions between generations of insect vectors can guarantee survival during adverse conditions for horizontal transmission, directly affecting viral ecology and epidemiology.

Maternal transmissions of plant viruses through transovarial passage is the most common mode of vertical transmission. During transovarial passage vertical transmission, the virus must pass through the membrane and tissue barriers of the ovary to infect oocytes (Hogenhout et al., 2008; Wei and Li, 2016; Wang and Blanc, 2021). The reproductive system of female insects is made up of a pair of ovaries, each of which contains several ovarioles, consisting of the terminal filament, germarium, vitellarium, and pedicel. Additionally, oocytes produced by the germarium are linearly arranged within the vitellarium, and surrounded by a layer of follicular cells (Büning, 1994; Szklarzewicz et al., 2007). Vitellogenin (Vg), a female-specific protein, is synthesized in the fat body, secreted into the hemolymph and absorbed by receptor-mediated endocytosis of the growing oocytes, thereby providing essential nutrients for embryonic development (Tufail and Takeda, 2008). Furthermore, the rice stripe virus (RSV) and TYLCV can directly bind Vg and enter oocytes from the germarium and follicular cells by appropriating the Vg transport route (Huo et al., 2014; Wei et al., 2017). Interestingly, $\mathrm{Vg}$ is also involved in mediating some facultative symbionts into the oocyte (Herren et al., 2013; Guo et al., 2018).

Obligate symbionts exhibit long-term co-evolutions with host insects, and are internalized into essential insect components, which are specifically manifested by the fact they are kept within specialized, enlarged insect cells, and are strictly vertically transmitted from the mother to offsprings (Buchner, 1965; Miura et al., 2003; Gottlieb et al., 2008; Sacchi et al., 2008). Obligate symbiotic bacteria have their own unique mechanisms through which they can gain entry into the ovary (from the posterior pole of the oocyte), in contrast to most plant viruses and facultative symbionts (Szklarzewicz and Michalik, 2017). Among the obligate symbiotic bacteria, an unusual phenomenon (termed "nested symbiosis") of symbiotic bacteria within other bacteria is sometimes found (Von Dohlen et al., 2001). For instance, Sodalis and Arsenophonus, facultative $\gamma$-proteobacterium symbionts of Cicadella viridis and Macrosteles laevis leafhoppers can pass through the envelope of the obligate symbiont Sulcia (Michalik et al., 2014; Kobiałka et al., 2016). Consequently, Sodalis and Arsenophonus can directly enter the cytoplasms of obligate bacteria to ensure their simultaneous transmission through insect generations (Michalik et al., 2014; Kobiałka et al., 2016). In some leafhoppers, Vg is incorporated into obligate symbionts, after which bacterial symbionts are exploited as independent carriers into oocytes (Mao et al., 2020). In conclusion, some insect components and microorganisms in insects can use obligate symbiotic bacteria as transporters and hitchhike the existing pathways to facilitate the entry of bacterial symbionts into insect oocytes.

The rice dwarf virus (RDV), belonging to the genus Phytoreovirus in the family Reoviridae, is an icosahedral, doublelayered particle. It has a diameter of $70 \mathrm{~nm}$, consists of one minor outer capsid protein P2 and one major outer capsid protein P8 (Omura et al., 1989, 1998). The green rice leafhopper, Nephotettix cincticeps, the main vector for RDV, is associated with two types of obligate symbiont bacteria-Sulcia and Nasuia (Honda et al., 2007; Noda et al., 2012). Besides, during their joint transovarial transmissions to the next insect generation, RDV, Sulcia, and Nasuia form complex tripartite interactions (Figure 1D; Jia et al., 2017). RDV virions migrate to ovaries and 
enter eggs by hitchhiking on Sulcia and Nasuia envelopes, and they simply benefit from vertical transmission routes taken by the two obligate bacterial symbiont partners in female $N$. cincticeps. In addition, RDV exploits its minor outer capsid protein P2 to interact with the BSA domain of OMP in the Sulcia envelope, inducing the formation of virus-containing invaginations or membrane-enclosed vesicles (Figure 1D, Table 1; Jia et al., 2017). In the case of Nasuia, through its major outer capsid protein P8, RDV interacts with porins in bacterial envelopes, thereby inducing the opening of porin channels for virions to pass through the outer membrane and into the periplasmic space (Figure 1D, Table 1; Wu W. et al., 2019). In this case, longterm coexistence of bacterial symbionts and plant viruses on their pathway into oocytes may result in specific evolutionary outcomes for cross-kingdom interactions between a virus and a bacterium in nature.

\section{CONCLUSION}

In summary, horizontal and vertical transmission of persistent plant viruses by vector insects involve complex interactions among viruses, vector components, and symbionts. In recent years, symbiotic bacteria that regulate the spread of persistent plant viruses through its insect vector have been extensively studied. For instance, Rickettsia has been shown to promote TYLCV acquisition, retention, and transmission through insects (Kliot and Ghanim, 2013; Kliot et al., 2019), GroEL maintains the stability of Geminivirus and Luteovirus virions in hemolymph (Hogenhout et al., 1998; Morin et al., 1999), Sulcia and Nasuia facilitate the transfer of RDV to the next generation (Jia et al., 2017; Wu W. et al., 2019). Elsewhere, studies have shown that gut microbiota in leafhopper and thrip do not influence the viral transmission efficiency (De Vries et al., 2012; Wang et al., 2019). Overall, the symbiotic microorganisms of various tissues play important regulatory roles in the transmission of persistent plant viruses through its insect vector. Therefore, bacterial symbionts have great potential for plant viral disease control. Up to now, the most successful strategy for viral disease control by symbiotic microorganisms is the introduction of certain strains of Wolbachia into A. aegypti for protecting humans from mosquitoborne diseases. Simlarly, the Wolbachia strain $w$ Stri (Isolated from the small brown planthopper, Laodelphax striatellus) has been stably introduced into brown planthopper, Nilaparvata lugens and shown to inhibited infection and transmission of

\section{REFERENCES}

Bello, V. H., Watanabe, L. F. M., Santos, B. R., Marubayashi, J. M., Yuki, V. A., De Marchi, B. R., et al. (2019). Evidence for increased efficiency of virus transmission by populations of mediterranean species of Bemisia tabaci with high Hamiltonella prevalence. Phytoparasitica 47, 293-300. doi: 10.1007/ s12600-019-00729-y

Bennett, G. M., and Moran, N. A. (2013). Small, smaller, smallest: the origins and evolution of ancient dual symbioses in a Phloem-feeding insect. Genome Biol. Evol. 5, 1675-1688. doi: 10.1093/gbe/evt118

Bing, X. L., Yang, J., Zchori-Fein, E., Wang, X. W., and Liu, S. S. (2013). Characterization of a newly discovered symbiont of the whitefly Bemisia tabaci
Rice ragged stunt virus (RRSV) and mitigated virus-induced symptoms in rice plants (Gong et al., 2020).

Although knowledge about the interplay among symbiotic microorganisms, insect vectors, and plant virus has rapidly expanded, there are several issues need further investigation. For instance, intestinal microbiota have been found to modulate immune responses, influence the physical status, or directly utilize microbiota-derived products to promote or inhibit arbovirus infection (Wu P. et al., 2019; Ma et al., 2021). Are there other symbionts involved in the regulation of persistent plant virus transmission through insect vectors? How do symbionts modulate virus infection in the insect vector? There is evidence that insect symbionts play important roles in insect-plant interactions (Frago et al., 2012). Virus-host plant-insect vector interactions mediate the process of virus release from salivary glands to infect host plants. Do symbionts influence virus transmission by regulating the tripartite interactions of the virushost plant-insect vector? To answer this question, in-depth understanding of the interactions among the virus, symbionts, insect vector, and host plant during persistent plant virus transmission through insect vectors is required. New approaches based on the large-scale high-throughput quantitative omics technologies including genomics, proteomics, metabolomics and transcriptomics will provide new opportunities to unravel the multiple interactions in the process of virus transmission by vector insects. Overall, the insights into insect-symbiotic microorganism-virus interactions may provide novel strategies for viral disease prevention in the future.

\section{AUTHOR CONTRIBUTIONS}

WW, H-WS, and QM: conceptualization. WW and QM: writing original draft preparation. WW, H-WS, J-ML, C-XZ, J-PC, and QM: writing, review, and editing. All authors have read and agreed to the published version of the manuscript.

\section{FUNDING}

This work was supported by National Natural Science Foundation of China (U20A2036 and 31870149), Ningbo Science and Technology Innovation 2025 Major Project (2019B10004), and K. C. Wong Magna Fund in Ningbo University.

(Hemiptera: Aleyrodidae). Appl. Environ. Microbiol. 79, 569-575. doi: 10.1128/ AEM.03030-12

Blanc, S., Drucker, M., and Uzest, M. (2014). Localizing viruses in their insect vectors. Annu. Rev. Phytopathol. 52, 403-425. doi: 10.1146/annurev-phyto102313-045920

Blow, F., and Douglas, A. E. (2019). The hemolymph microbiome of insects. J. Insect. Physiol. 115, 33-39. doi: 10.1016/j.jinsphys.2019.0 4.002

Bouvaine, S., Boonham, N., and Douglas, A. E. (2011). Interactions between a luteovirus and the GroEL chaperonin protein of the symbiotic bacterium Buchnera aphidicola of aphids. J. Gen. Virol. 92, 1467-1474. doi: 10.1099/vir. 0.029355-0 
Brown, J. K., and Czosnek, H. (2002). Whitefly transmission of plant viruses. Adv. Bot. Res. 36, 65-100. doi: 10.1016/S0065-2296(02)36059-2

Brumin, M., Levy, M., and Ghanim, M. (2012). Transovarial transmission of Rickettsia spp. and organ-specific infection of the Whitefly Bemisia tabaci. Appl. Environ. Microbiol. 78, 5565-5574. doi: 10.1128/aem.01184-12

Buchner, P. (1965). EndosyMbiosis Of Animals With Plant Microorganisms. Geneva: Interscience Publishers.

Büning, J. (1994). The Insect Ovary: Ultrastructure, Previtellogenic Growth And Evolution. Berlin: Springer Science \& Business Media.

Burke, G., Fiehn, O., and Moran, N. (2010). Effects of facultative syMbionts and heat stress on the metabolome of pea aphids. ISME J. 4, 242-252. doi: 10.1038/ ismej.2009.114

Chaudhary, R., Atamian, H. S., Shen, Z., Briggs, S. P., and Kaloshian, I. (2014). GroEL from the endosyMbiont Buchnera aphidicola betrays the aphid by triggering plant defense. Proc. Natl. Acad. Sci. U.S. A. 111, 8919-8924. doi: $10.1073 /$ pnas. 1407687111

Chen, X., Yu, J., Wang, W., Lu, H., Kang, L., and Cui, F. (2020). A plant virus ensures viral stability in the hemolymph of vector insects through suppressing prophenoloxidase activation. Mbio 11, e1453-e1520. doi: 10.1128/Mbio.014 53-20

Chen, Y. Z., Singh, A., Kaithakottil, G. G., Mathers, T. C., Gravino, M., Mugford, S. T., et al. (2020). An aphid RNA transcript migrates systemically within and is a virulence factor. Proc. Natl. Acad. Sci. U.S. A. 117, 12763-12771. doi: 10.1073/pnas.1918410117

Cilia, M., Tamborindeguy, C., Fish, T., Howe, K., Thannhauser, T. W., and Gray, S. (2011). Genetics coupled to quantitative intact proteomics links heritable aphid and endosymbiont protein expression to circulative polerovirus transmission. J. Virol. 85, 2148-2166. doi: 10.1128/JVI.01504-10

Cirimotich, C. M., Ramirez, J. L., and Dimopoulos, G. (2011). Native microbiota shape insect vector competence for human pathogens. Cell Host Microbe 10, 307-310. doi: 10.1016/j.chom.2011.09.006

De Vries, J. E., De Wetering, V. F., Van Der Hoek, M. M., Jacobs, G., and Breeuwer, A. J. J. (2012). Symbiotic bacteria (Erwinia sp.) in the gut of Frankliniella occidentalis (Thysanoptera: Thripidae) do not affect its ability to transmit tospovirus. EJE 109, 261-266. doi: 10.14411/eje.2012.034

Dedryver, C. A., Le Ralec, A., and Fabre, F. (2010). The conflicting relationships between aphids and men: a review of aphid damage and control strategies. C. $R$. Biologies 333, 539-553. doi: 10.1016/j.crvi.2010.03.009

Douglas, A. E. (2011). Lessons from studying insect symbioses. Cell Host Microbe 10, 359-367. doi: 10.1016/j.chom.2011.09.001

Duron, O., and Hurst, G. D. (2013). Arthropods and inherited bacteria: from counting the symbionts to understanding how syMbionts count. BMC Biol. 11:45. doi: 10.1186/1741-7007-11-45

Edelbaum, D., Gorovits, R., Sasaki, S., Ikegami, M., and Czosnek, H. (2009). Expressing a whitefly GroEL protein in Nicotiana benthamiana plants confers tolerance to tomato yellow leaf curl virus and cucumber mosaic virus, but not to grapevine virus A or tobacco mosaic virus. Arch. Virol. 154, 399-407. doi: 10.1007/s00705-009-0317-9

Everett, K. D. E., Thao, M. L., Horn, M., Dyszynski, G. E., and Baumann, P. (2005). Novel chlamydiae in whiteflies and scale insects: endosyMbionts 'Candidatus Fritschea bemisiae' strain Falk and 'Candidatus Fritschea eriococci' strain Elm. Int. J. Syst. Evol. Microbiol. 55, 1581-1587. doi: 10.1099/ijs.0.63454-0

Filichkin, S. A., Brumfield, S., Filichkin, T. P., and Young, M. J. (1997). In vitro interactions of the aphid endosymbiotic Syml chaperonin with barley yellow dwarf virus. J. Virol. 71, 569-577. doi: 10.1128/jvi.71.1.569-577.1997

Frago, E., Dicke, M., and Godfray, H. C. (2012). Insect symbionts as hidden players in insect-plant interactions. Trends Ecol. Evol. 27, 705-711. doi: 10.1016/j.tree. 2012.08.013

Gao, H., Cui, C., Wang, L., Jacobs-Lorena, M., and Wang, S. (2020). Mosquito microbiota and implications for disease control. Trends Parasitol. 36, 98-111. doi: 10.1016/j.pt.2019.12.001

Gong, J. T., Li, Y., Li, T. P., Liang, Y., Hu, L., Zhang, D., et al. (2020). Stable introduction of plant-virus-inhibiting Wolbachia into planthoppers for rice protection. Curr. Biol. 30, 4837-4845. doi: 10.1016/j.cub.2020.09.033

Gottlieb, Y., Ghanim, M., Chiel, E., Gerling, D., Portnoy, V., Steinberg, S., et al. (2006). Identification and localization of a Rickettsia sp. in Bemisia tabaci (Homoptera: Aleyrodidae). Appl. Environ. Microbiol. 72, 3646-3652. doi: 10. 1128/AEM.72.5.3646-3652.2006
Gottlieb, Y., Ghanim, M., Gueguen, G., Kontsedalov, S., Vavre, F., Fleury, F., et al. (2008). Inherited intracellular ecosystem: symbiotic bacteria share bacteriocytes in whiteflies. FASEB J. 22, 2591-2599. doi: 10.1096/fj.07-101162

Gottlieb, Y., Zchori-Fein, E., Mozes-Daube, N., Kontsedalov, S., Skaljac, M., Brumin, M., et al. (2010). The transmission efficiency of tomato yellow leaf curl virus by the whitefly Bemisia tabaci is correlated with the presence of a specific symbiotic bacterium species. J. Virol. 84, 9310-9317. doi: 10.1128/JVI.00423-10

Gray, S., Cilia, M., and Ghanim, M. (2014). "Chapter four - Circulative, "Nonpropagative" virus transmission: an orchestra of virus-, insect-, and plantderived instruments," in Advances in Virus Research, eds K. Maramorosch and F. A. Murphy (Cambridge, MA: Academic Press), 141-199. doi: 10.1016/B978$0-12-800172-1.00004-5$

Gross, R., Vavre, F., Heddi, A., Hurst, G. D., Zchori-Fein, E., and Bourtzis, K. (2009). Immunity and symbiosis. Mol. Microbiol. 73, 751-759. doi: 10.1111/j. 1365-2958.2009.06820.x

Guo, J. Q., Hatt, S., He, K. L., Chen, J. L., Francis, F., and Wang, Z. Y. (2017). Nine facultative endosyMbionts in aphids. A review. J. Asia Pacific Entomol. 20, 794-801. doi: 10.1016/j.aspen.2017.03.025

Guo, Y., Hoffmann, A. A., Xu, X. Q., Mo, P. W., Huang, H. J., Gong, J. T., et al. (2018). Vertical Transmission of Wolbachia is associated with host vitellogenin in Laodelphax striatellus. Front. Microbiol. 9:2016. doi: 10.3389/fmicb.2018. 02016

Hansen, A. K., and Moran, N. A. (2011). Aphid genome expression reveals hostsymbiont cooperation in the production of amino acids. Proc. Natl. Acad. Sci. U.S. A. 108, 2849-2854. doi: 10.1073/pnas.1013465108

Hansen, A. K., and Moran, N. A. (2014). The impact of microbial symbionts on host plant utilization by herbivorous insects. Mol. Ecol. 23, 1473-1496. doi: $10.1111 / \mathrm{mec} .12421$

He, Y. Z., Wang, Y. M., Yin, T. Y., Cuellar, W. J., Liu, S. S., and Wang, X. W. (2021). Gut-Expressed Vitellogenin facilitates the movement of a plant virus across the midgut wall in its insect vector. mSystems 6:e0058121. doi: 10.1128/mSystems. 00581-21

Herren, J. K., Paredes, J. C., Schupfer, F., and Lemaitre, B. (2013). Vertical transmission of a drosophila endosymbiont via cooption of the yolk transport and internalization machinery. Mbio 4:2. doi: 10.1128/Mbio.00532-12

Hogenhout, S. A., Ammar el, D., Whitfield, A. E., and Redinbaugh, M. G. (2008). Insect vector interactions with persistently transmitted viruses. Annu. Rev. Phytopathol. 46, 327-359. doi: 10.1146/annurev.phyto.022508.09 2135

Hogenhout, S. A., van der Wilk, F., Verbeek, M., Goldbach, R. W., and van den Heuvel, J. F. (1998). Potato leafroll virus binds to the equatorial domain of the aphid endosymbiotic groel homolog. J. Virol. 72, 358-365. doi: 10.1128/JVI.72. $1.358-365.1998$

Hogenhout, S. A., Verbeek, M., Hans, F., Houterman, P. M., Fortass, M., vanderWilk, F., et al. (1996). Molecular bases of the interactions between luteoviruses and aphids. Agronomie 16, 167-173. doi: 10.1051/agro:19960304

Honda, K., Wei, T. Y., Hagiwara, K., Higashi, T., Kimura, I., Akutsu, K., et al. (2007). Retention of rice dwarf virus by descendants of pairs of viruliferous vector insects after rearing for 6 years. Phytopathology 97, 712-716. doi: 10. 1094/phyto-97-6-0712

Hosokawa, T., Kikuchi, Y., Shimada, M., and Fukatsu, T. (2007). Obligate symbiont involved in pest status of host insect. Proc. Biol. Sci. 274, 1979-1984. doi: 10.1098/rspb.2007.0620

Huo, Y., Liu, W. W., Zhang, F. J., Chen, X. Y., Li, L., Liu, Q. F., et al. (2014). Transovarial transmission of a plant virus is mediated by Vitellogenin of its insect vector. PLoS Pathog. 10:e1003949. doi: 10.1371/journal.ppat.1003949

Jia, D., Chen, Q., Mao, Q., Zhang, X., Wu, W., Chen, H., et al. (2018). Vector mediated transmission of persistently transmitted plant viruses. Curr. Opin. Virol. 28, 127-132. doi: 10.1016/j.coviro.2017.12.004

Jia, D., Mao, Q., Chen, Y., Liu, Y., Chen, Q., Wu, W., et al. (2017). Insect symbiotic bacteria harbour viral pathogens for transovarial transmission. Nat. Microbiol. 2:17025. doi: 10.1038/nmicrobiol.2017.25

Jing, X., Wong, A. C., Chaston, J. M., Colvin, J., McKenzie, C. L., and Douglas, A. E. (2014). The bacterial communities in plant phloem-sap-feeding insects. Mol. Ecol. 23, 1433-1444. doi: 10.1111/mec.12637

Jones, R. A. C., and Naidu, R. A. (2019). Global dimensions of plant virus diseases: current status and future perspectives. Annu. Rev. Virol. 6, 387-409. doi: 10. 1146/annurev-virology-092818-015606 
Ju, J. F., Bing, X. L., Zhao, D. S., Guo, Y., Xi, Z. Y., Hoffmann, A. A., et al. (2020). Wolbachia supplement biotin and riboflavin to enhance reproduction in planthoppers. ISME J. 14, 676-687. doi: 10.1038/s41396-019-0559-9

Khan, M. U., Li, P. H., Amjad, H., Khan, A. Q., Arafat, Y., Waqas, M., et al. (2019). Exploring the potential of overexpressed oscipk2 rice as a nitrogen utilization efficient crop and analysis of its associated rhizo-compartmental microbial communities. Int. J. Mol. Sci. 20:3636. doi: 10.3390/ijms20153636

Kliot, A., and Ghanim, M. (2013). The role of bacterial chaperones in the circulative transmission of plant viruses by insect vectors. Viruses 5, 1516-1535. doi: 10. 3390/v5061516

Kliot, A., Cilia, M., Czosnek, H., and Ghanim, M. (2014). Implication of the bacterial endosymbiont Rickettsia spp. in interactions of the whitefly Bemisia tabaci with tomato yellow leaf curl virus. J. Virol. 88, 5652-5660. doi: 10.1128/ JVI.00071-14

Kliot, A., Kontsedalov, S., Lebedev, G., Czosnek, H., and Ghanim, M. (2019). Combined infection with tomato yellow leaf curl virus and rickettsia influences fecundity, attraction to infected plants and expression of immunity-related genes in the whitefly Bemisia tabaci. J. Gen. Virol. 100, 721-731. doi: 10.1099/ jgv.0.001233

Kobiałka, M., Michalik, A., Walczak, M., Junkiert, L., and Szklarzewicz, T. (2016). Sulcia symbiont of the leafhopper Macrosteles laevis (Ribaut, 1927) (Insecta, Hemiptera, Cicadellidae: Deltocephalinae) harbors Arsenophonus bacteria. Protoplasma 253, 903-912. doi: 10.1007/s00709-015-0854-x

Latorre, A., and Manzano-Marin, A. (2017). Dissecting genome reduction and trait loss in insect endosyMbionts. Ann. N. Y .Acad. Sci. 1389, 52-75. doi: $10.1111 /$ nyas. 13222

Lavine, M. D., and Strand, M. R. (2002). Insect hemocytes and their role in immunity. Insect Biochem. Mol. Biol. 32, 1295-1309.

Lei, T., Zhao, J., Wang, H. L., Liu, Y. Q., and Liu, S. S. (2021). Impact of a novel Rickettsia symbiont on the life history and virus transmission capacity of its host whitefly (Bemisia tabaci). Insect Sci. 28, 377-391. doi: 10.1111/1744-7917.12797

Liu, S., Sivakumar, S., Wang, Z., Bonning, B. C., and Miller, W. A. (2009). The readthrough domain of pea enation mosaic virus coat protein is not essential for virus stability in the hemolymph of the pea aphid. Arch. Virol. 154, 469-479. doi: 10.1007/s00705-009-0327-7

Liu, W., Gray, S., Huo, Y., Li, L., Wei, T., and Wang, X. (2015). Proteomic analysis of interaction between a plant virus and its vector insect reveals new functions of hemipteran cuticular protein. Mol. Cell Proteomics 14, 2229-2242. doi: 10.1074/mcp.M114.046763

Luan, J. B., Shan, H. W., Isermann, P., Huang, J. H., Lammerding, J., Liu, S. S., et al. (2016). Cellular and molecular remodelling of a host cell for vertical transmission of bacterial symbionts. Proc. Biol. Sci. 283:20160580. doi: 10.1098/ rspb.2016.0580

Ma, E., Zhu, Y., Liu, Z., Wei, T., Wang, P., and Cheng, G. (2021). Interaction of viruses with the insect intestine. Annu. Rev. Virol. 8, 115-131. doi: 10.1146/ annurev-virology-091919-100543

Mao, Q., Liao, Z., Li, J., Liu, Y., Wu, W., Chen, H., et al. (2017). Filamentous structures induced by a Phytoreovirus mediate viral release from salivary glands in its insect vector. J. Virol. 91:e00265-17. doi: 10.1128/JVI.00265-17

Mao, Q. Z., Wu, W., Huang, L. Z., Yi, G., Jia, D. S., Chen, Q., et al. (2020). Insect bacterial symbiont-mediated vitellogenin uptake into oocytes to support egg development. Mbio 11, e01142-e01220. doi: 10.1128/Mbio.01142-20

Michalik, A., Golas, A., Kot, M., Wieczorek, K., and Szklarzewicz, T. (2013). Endosymbiotic microorganisms in Adelges (Sacchiphantes) viridis (Insecta, Hemiptera, Adelgoidea: Adelgidae): molecular characterization, ultrastructure and transovarial transmission. Arthropod Struct. Dev. 42, 531-538. doi: 10.1016/ j.asd.2013.09.004

Michalik, A., Jankowska, W., Kot, M., Golas, A., and Szklarzewicz, T. (2014). Symbiosis In the green leafhopper. Cicadella viridis (Hemiptera, Cicadellidae). association in statu nascendi?. Arthropod Struct. Dev. 43, 579-587. doi: 10.1016/ j.asd.2014.07.005

Miura, T., Braendle, C., Shingleton, A., Sisk, G., Kambhampati, S., and Stern, D. L. (2003). A comparison of parthenogenetic and sexual embryogenesis of the pea aphid Acyrthosiphon pisum (Hemiptera: Aphidoidea). J. Exp. Zool. B Mol. Dev. Evol. 295, 59-81. doi: 10.1002/jez.b.3

Moran, N. A. (2007). Symbiosis as an adaptive process and source of phenotypic complexity. Proc. Natl. Acad. Sci. U.S. A. <refvol>104(Suppl. 1), 8627-8633. doi: $10.1073 /$ pnas.0611659104
Moran, N. A., and Bennett, G. M. (2014). The tiniest tiny genomes. Annu. Rev. Microbiol. 68, 195-215. doi: 10.1146/annurev-micro-091213-112901

Moran, N. A., Dunbar, H. E., and Wilcox, J. L. (2005). Regulation of transcription in a reduced bacterial genome: nutrient-provisioning genes of the obligate symbiont Buchnera aphidicola. J. Bacteriol. 187, 4229-4237. doi: 10.1128/JB. 187.12.4229-4237.2005

Moran, N. A., McCutcheon, J. P., and Nakabachi, A. (2008). Genomics and evolution of heritable bacterial syMbionts. Annu. Rev. Genet. 42, 165-190. doi: 10.1146/annurev.genet.41.110306.130119

Morin, S., Ghanim, M., Zeidan, M., Czosnek, H., Verbeek, M., and Van Den Heuvel, J. F. (1999). A groel homologue from endosyMbiotic bacteria of the whiteflyBemisia tabaciis implicated in the circulative transmission of tomato yellow leaf curl virus. Virology 256, 75-84.

Newell, P. D., and Douglas, A. E. (2014). Interspecies interactions determine the impact of the gut microbiota on nutrient allocation in Drosophila melanogaster. Appl. Environ. Microbiol. 80, 788-796. doi: 10.1128/AEM.02742-13

Ng, J. C., and Falk, B. W. (2006). Virus-vector interactions mediating nonpersistent and semipersistent transmission of plant viruses. Annu. Rev. Phytopathol. 44, 183-212. doi: 10.1146/annurev.phyto.44.070505.143325

Nirgianaki, A., Banks, G. K., Frohlich, D. R., Veneti, Z., Braig, H. R., Miller, T. A., et al. (2003). Wolbachia infections of the whitefly Bemisia tabaci. Curr. Microbiol. 47, 93-101. doi: 10.1007/s00284-002-3969-1

Noda, H. (1977). Histological and histochemical observation of intracellular yeastlike symbiotes in the fat body of the smaller brown planthopper. Laodelphax striatellus (Homoptera: Delphacidae). Appl. Entomol. Zool. 12, 134141.

Noda, H., Watanabe, K., Kawai, S., Yukuhiro, F., Miyoshi, T., Tomizawa, M., et al. (2012). Bacteriome-associated endosymbionts of the green rice leafhopper Nephotettix cincticeps (Hemiptera: Cicadellidae). Appl. Entomol. Zool. 47, 217225. doi: 10.1007/s13355-012-0110-1

Noman, A., Aqeel, M., Qasim, M., Haider, I., and Lou, Y. G. (2020). Plant-insectmicrobe interaction: a love triangle between enemies in ecosystem. Sci. Total Environ. 699:134181. doi: 10.1016/j.scitotenv.2019.134181

Oliver, K. M., Russell, J. A., Moran, N. A., and Hunter, M. S. (2003). Facultative bacterial symbionts in aphids confer resistance to parasitic wasps. Proc. Natl. Acad. Sci. U.S.A. 100, 1803-1807. doi: 10.1073/pnas.0335320100

Omura, T., Ishikawa, K., Hirano, H., Ugaki, M., Minobe, Y., Tsuchizaki, T., et al. (1989). The outer capsid protein of rice dwarf virus is encoded by genome segment S8. J. Gen. Virol. 70, 2759-2764. doi: 10.1099/0022-1317-70-10-2759

Omura, T., Yan, J., Zhong, B. X., Wada, M., Zhu, Y. F., Tomaru, M., et al. (1998). The P2 protein of rice dwarf phytoreovirus is required for adsorption of the virus to cells of the insect vector. J. Virol. 72, 9370-9373. doi: 10.1128/jvi.72.11. 9370-9373.1998

Piana, S., and Shaw, D. E. (2018). Atomic-level description of protein folding inside the groel cavity. J. Phys. Chem. B 122, 11440-11449. doi: 10.1021/acs. jpcb.8b07366

Pyka-Fosciak, G., and Szklarzewicz, T. (2003). Germ cell cluster formation and ovariole structure in viviparous and oviparous generations of the aphid Stomaphis quercus. Int. J. Dev. Biol. 52, 259-265.

Ramirez, J. L., Souza-Neto, J., Torres Cosme, R., Rovira, J., Ortiz, A., Pascale, J. M., et al. (2012). Reciprocal tripartite interactions between the Aedes aegypti midgut microbiota, innate immune system and dengue virus influences vector competence. PLoS Negl. Trop. Dis. 6:e1561. doi: 10.1371/journal.pntd.0001561

Rana, V. S., Singh, S. T., Priya, N. G., Kumar, J., and Rajagopal, R. (2012). Arsenophonus groel interacts with clcuv and is localized in midgut and salivary gland of Whitefly B. tabaci. PLoS One 7:e42168. doi: 10.1371/journal.pone. 0042168

Rio, R. V. M., Attardo, G. M., and Weiss, B. L. (2016). Grandeur alliances: symbiont metabolic integration and obligate arthropod hematophagy. Trends Parasitol. 32, 739-749. doi: 10.1016/j.pt.2016.05.002

Sacchi, L., Genchi, M., Clementi, E., Bigliardi, E., Avanzati, A. M., Pajoro, M., et al. (2008). Multiple symbiosis in the leafhopper Scaphoideus titanus (Hemiptera: Cicadellidae): details of transovarial transmission of Cardinium sp. and yeastlike endosymbionts. Tissue Cell 40, 231-242. doi: 10.1016/j.tice.2007.12.005

Saraiva, R. G., Fang, J., Kang, S., Anglero-Rodriguez, Y. I., Dong, Y., and Dimopoulos, G. (2018). Aminopeptidase secreted by Chromobacterium sp. Panama inhibits dengue virus infection by degrading the E protein. PLoS Negl. Trop. Dis. 12:e006443. doi: 10.1371/journal.pntd.0006443 
Sasaki, T., Kawamura, M., and Ishikawa, H. (1996). Nitrogen recycling in the brown planthopper. Nilaparvata lugens: involvement of yeast-like endosyMbionts in uric acid metabolism. J. Insect Physiol. 42, 125-129. doi: 10.1016/0022-1910(95)00086-0

Shane, J. L., Grogan, C. L., Cwalina, C., and Lampe, D. J. (2018). Blood mealinduced inhibition of vector-borne disease by transgenic microbiota. Nat. Commun. 9:4127. doi: 10.1038/s41467-018-06580-9

Shi, X. B., Yan, S., Zhang, C., Zheng, L. M., Zhang, Z. H., Sun, S. E., et al. (2021). Aphid endosymbiont facilitates virus transmission by modulating the volatile profile of host plants. BMC Plant Biol. 21:67. doi: 10.1186/s12870-021-02 838-5

Simon, J. C., Biere, A., and Sugio, A. (2017). The promises and challenges of research on plant-insect-microbe interactions. Insect Sci. 24, 904-909. doi: 10. 1111/1744-7917.12536

Sloan, D. B., and Moran, N. A. (2012). Endosymbiotic bacteria as a source of carotenoids in whiteflies. Biol. Lett. 8, 986-989. doi: 10.1098/rsbl.2012.0664

Stevens, L., Giordano, R., and Fialho, R. F. (2001). Male-killing,nematode infections, bacteriophage infection, and virulence of cytoplasmic bacteria in the genus Wolbachia. Ann. Rev. Ecol. Syst. 32, 519-545. doi: 10.1146/annurev. ecolsys.32.081501.114132

Su, Q., Pan, H., Liu, B., Chu, D., Xie, W., Wu, Q., et al. (2013). Insect symbiont facilitates vector acquisition, retention, and transmission of plant virus. Sci. Rep. 3:1367. doi: 10.1038/srep01367

Szklarzewicz, T., and Michalik, A. (2017). Transovarial transmission of symbionts in insects. Results Prob. Cell Differ. 63, 43-67. doi: 10.1007/978-3-319-608 55-6_3

Szklarzewicz, T., Grzywacz, B., Szwedo, J., and Michalik, A. (2016). Bacterial symbionts of the leafhopper Evacanthus interruptus (Linnaeus, 1758) (Insecta. Hemiptera, Cicadellidae: Evacanthinae). Protoplasma 253, 379-391. doi: 10. 1007/s00709-015-0817-2

Szklarzewicz, T., Jankowska, W., Lukasiewicz, K., and Szymanska, B. (2007). Structure of the ovaries and oogenesis in Cixius nervosus (Cixiidae). Javesella pellucida and Conomelus anceps (Delphacidae) (Insecta, Hemiptera, Fulgoromorpha). Arthropod Struct. Dev. 36, 199-207. doi: 10.1016/j.asd.2006. 09.001

Szklarzewicz, T., Swierczewski, D., Stroinski, A., and Michalik, A. (2020). Conservatism and stability of the symbiotic system of the invasive alien treehopper Stictocephala bisonia (Hemiptera. Cicadomorpha, Membracidae). Ecol. Entomol. 45, 876-885. doi: 10.1111/een.12861

Thao, M. L., and Baumann, P. (2004). Evolutionary relationships of primary prokaryotic endosymbionts of whiteflies and their hosts. Appl. Environ. Microbiol. 70, 3401-3406. doi: 10.1128/Aem.70.6.3401-3406.2004

Tsuchida, T., Koga, R., and Fukatsu, T. (2004). Host plant specialization governed by facultative symbiont. Science 303:1989. doi: 10.1126/science.109 4611

Tsuchida, T., Koga, R., Horikawa, M., Tsunoda, T., Maoka, T., Matsumoto, S., et al. (2010). Symbiotic bacterium modifies aphid body color. Science 330, 1102-1104. doi: 10.1126/science. 1195463

Tufail, M., and Takeda, M. (2008). Molecular characteristics of insect Vitellogenins. J. Insect Physiol. 54, 1447-1458. doi: 10.1016/j.jinsphys.2008.08.007

Van den Heuvel, J. F., Verbeek, M., and van der Wilk, F. (1994). Endosymbiotic bacteria associated with circulative transmission of potato leafroll virus by Myzus persicae. J. Gen. Virol. 75, 2559-2565. doi: 10.1099/0022-1317-75-102559

van den Heuvel, J., Bruyere, A., Hogenhout, A., ZieglerGraff, V., Brault, V., Verbeek, M., et al. (1997). The N-terminal region of the luteovirus readthrough domain determines virus binding to Buchnera GroEL and is essential for virus persistence in the aphid. J. Virol. 71, 7258-7265. doi: 10.1128/jvi.71.10.72587265.1997
Von Dohlen, C. D., Kohler, S., Alsop, S. T., and McManus, W. R. (2001). Mealybug beta-proteobacterial endosymbionts contain gamma-proteobacterial symbionts. Nature 412, 433-436. doi: 10.1038/35086563

Wang, H., Wu, N., Liu, Y., Kundu, J. K., Liu, W., and Wang, X. (2019). Higher bacterial diversity of gut microbiota in different natural populations of leafhopper vector does not influence WDV transmission. Front. Microbiol. 10:1144. doi: 10.3389/fmicb.2019.01144

Wang, X. W., and Blanc, S. (2021). Insect transmission of plant single-stranded DNA Viruses. Annu. Rev. Entomol. 66, 389-405. doi: 10.1146/annurev-ento060920-094531

Weeks, A. R., Velten, R., and Stouthamer, R. (2003). Incidence of a new sex-ratiodistorting endosymbiotic bacterium among arthropods. Proc. R. Soci. B Biol. Sci. 270, 1857-1865. doi: 10.1098/rspb.2003.2425

Wei, J., He, Y. Z., Guo, Q., Guo, T., Liu, Y. Q., Zhou, X. P., et al. (2017). Vector development and vitellogenin determine the transovarial transmission of begomoviruses. Proc. Natl. Acad. Sci. U.S. A. 114, 6746-6751. doi: 10.1073/ pnas.1701720114

Wei, T., and Li, Y. (2016). Rice reoviruses in insect vectors. Annu. Rev. Phytopathol. 54, 99-120. doi: 10.1146/annurev-phyto-080615-095900

Werren, J. H., Baldo, L., and Clark, M. E. (2008). Wolbachia: master manipulators of invertebrate biology. Nat. Rev. Microbiol. 6, 741-751. doi: 10.1038/ nrmicro1969

Wilson, J. R., Deblasio, S. L., Alexander, M. M., and Heck, M. (2020). Looking through the lens of 'omics technologies: insights into the transmission of insect vector-borne plant viruses. Curr. Issues Mol. Biol. 34, 113-144. doi: 10.21775/ cimb.034.113

Wu, P., Sun, P., Nie, K., Zhu, Y., Shi, M., Xiao, C., et al. (2019). A gut commensal bacterium promotes mosquito permissiveness to Arboviruses. Cell Host Microbe < refvol > 10:e105. doi: 10.1016/j.chom.2018.11.004

Wu, W., Huang, L. Z., Mao, Q. Z., Wei, J., Li, J. J., Zhao, Y., et al. (2019). Interaction of viral pathogen with porin channels on the outer membrane of insect bacterial syMbionts mediates their joint transovarial transmission. Philos. Trans. R. Soc. B Biol. Sci. 374:20180320.

$\mathrm{Xu}, \mathrm{Y}$., Fu, S., Tao, X., and Zhou, X. (2021). Rice stripe virus: exploring molecular weapons in the arsenal of a negative-sense RNA Virus. Annu. Rev. Phytopathol. 59, 351-371. doi: 10.1146/annurev-phyto-020620-113020

Yin, C., Sun, P., Yu, X., Wang, P., and Cheng, G. (2020). Roles of symbiotic microorganisms in arboviral infection of arthropod vectors. Trends Parasitol. 36, 607-615. doi: 10.1016/j.pt.2020.04.009

Zchori-Fein, E., and Brown, J. K. (2002). Diversity of prokaryotes associated with Bemisia tabaci (Gennadius) (Hemiptera : Aleyrodidae). Ann. Entomol. Soc. Am. 95, 711-718.

Conflict of Interest: The authors declare that the research was conducted in the absence of any commercial or financial relationships that could be construed as a potential conflict of interest.

Publisher's Note: All claims expressed in this article are solely those of the authors and do not necessarily represent those of their affiliated organizations, or those of the publisher, the editors and the reviewers. Any product that may be evaluated in this article, or claim that may be made by its manufacturer, is not guaranteed or endorsed by the publisher.

Copyright (c) $2022 \mathrm{Wu}$, Shan, Li, Zhang, Chen and Mao. This is an open-access article distributed under the terms of the Creative Commons Attribution License (CC BY). The use, distribution or reproduction in other forums is permitted, provided the original author(s) and the copyright owner(s) are credited and that the original publication in this journal is cited, in accordance with accepted academic practice. No use, distribution or reproduction is permitted which does not comply with these terms. 